\title{
Towards a Miltonic Mariology: the word and the body of Mary in Paradise Regain'd (1671)
}

\author{
Joan Curbet Soler \\ Universitat Autònoma de Barcelona
}

\begin{abstract}
It is a recurring critical topos that John Milton's Paradise Regain'd (1671) is a revisionist poem, one that works towards reframing and redefining the epic tradition; what has certainly been less noticed is the central function played by the character of Mary, the mother of Christ, in this revisionist process. This article will try to prove that Mary's appearances in the poem are, though limited, essential to its content and to its perspective on the interrelated subjects of the revelation of God in history and the individual confrontation with historical forces; and it will try to do so by bringing together theological discussion and a genderoriented approach.
\end{abstract}

There have certainly been approaches to Paradise Regain'd that have explored some of the gender issues brought about by the poem's modification of the heroic function: almost unanimously, these approaches have concentrated on the character of the Son. My intention here, however, is another: I will try to show how the function and voice of Mary in the poem set in motion a complex, rich network of implications (both ethical and theological) which are at the core of the poem's discourse and ideology. This focus on the maternal in Paradise Regain'd will not be carried out from a psychoanalytical perspective (though it is by no means incompatible with such an approach), but rather through reading the text via literary and theological categories that are recurrent throughout Milton's work. It should thus be possible to start working seriously towards establishing the presence of a serious and original Mariology (clearly not a Mariolatry) in Milton's last epic poem. 
Overall, this will lead us to a reconsideration of Paradise Regain'd as an essentially innovative text, and one which is strongly heterodox in terms of its theology and gender discourse.

KEY WORDS: Gender, motherhood, selfhood, epic.

In a very literal sense, Milton scholarship is dominated by its tendency to return to the mother: despite its seemingly inexhaustible variety of approaches, it has always tended to situate the figure of the original mother of humanity, Eve, as one of its key centres of discourse, and will probably (and productively) continue to do so in the future. If this is abundantly justified by the powerful and ambivalent presence of Eve in Paradise Lost, it has largely implied the critical overshadowing of the other central motherly presence in the Miltonic canon: the figure of Mary, the mother of Christ, in Paradise Regain' $d$. This fact is all the more remarkable given the fact that this latter text is widely recognized as a theologically and formally complex, even revisionist poem; what has certainly been less noticed is the central function played by Mary in its conceptual and poetic structure.

The present article will try to prove that Mary's appearances in Paradise Regain'd are, though limited, essential to its content and to the poem's perspective on two interrelated subjects: the construction of selfhood in its relation to God's will and the revelation of Christ in history. I will show how the presence and voice of Mary in the text set in motion a complex, rich network of implications which are at the core of the poem's discourse and ideology. In the first place, I will put a special emphasis on the model of selfhood or self-building that her character exemplifies in Book II, lines 66-104, and which also serves as a key referent for the identity which the Son himself learns to develop; in the second place, and through a analysis of her voice as evoked by Christ in his first monologue (Book I, lines 196-293), this discourse on selfhood will be read as the basis for the theological significance that Milton projects into her character and its relation with her son (the Son), and which he adapts creatively from sources reaching as far back as the Patristic tradition. My focus on the maternal in Paradise Regain'd will be carried out through a complementary analysis of its ethical (in the Foucauldian sense of the term) and theological aspects; it should thus be possible to start working seriously towards establishing the presence of a serious and 
original Mariology, though clearly not a Mariolatry, in Milton's last epic poem.

\section{Critical/Theological Contexts}

The serious lack of critical attention to the character of Mary through the history of the reception of Paradise Regain'd could indeed seem to be, in itself, an ironic reflection of the very attitude of modesty and self-effacement that she adopts in her speeches. Ralph Condee's long landmark article of 1970, that did so much to re-situate the poem at the forefront of Milton studies, made no more than a brief reference to the character, presenting her as embodying "the themes of concealment and discovery" that are at the heart of the short epic: her interrogative attitude towards her son, her desire to know more about his whereabouts and destiny, could thus appear as a reflection of Christ's own quest for his own identity and role (Condee 1970:360-361). The main theological discussions of the poem (such as those by Barbara Kiefer Lewalski [1975] or by Thomas Langford [1982]) have rigorously excluded the figure of Mary, in a movement that is coherent with the central theology of the poem itself (which is fully centred on Christ), but this is a pattern that has tended to repeat itself in studies concerned with other thematic or political aspects: for instance, in the case of Louis L. Martz's Milton: Poet of Exile, where she receives only the briefest of mentions, with the emphasis being put not so much on her role but on her voice, her stylistic austerity and "biblical simplicity of phrasing,"which are opposed to the "high oratorical style" that is the prerogative of Satan (Martz 1980:256). A couple of major studies have examined the possible connections and parallelisms between the fictional representation of Christ and the personal and poetic situation of Milton himself when writing the poem (Corns 2003; Fallon 2007), but neither of them has paid any attention to the protagonist's mother. Finally, in one of the longest studies of Paradise Regain'd published in the last decade, Stanley Fish dedicates only a short paragraph to Mary, presenting her as the quintessential example of the inaction that is apparently celebrated in the poem as a whole: for Fish, "waiting is the only action that the characters in Paradise Regain'd ever take," and this applies to her as well: her "moving expression of a mother's anxieties is preliminary to a similar declaration of passivity" (Fish 2002:329). All of these responses to Milton's version of Mary are, in 
their own way, correct; all of them are nevertheless insufficient, insomuch as they lead us to overlook her major generative role within the text.

In order to appreciate the Miltonic innovations on the character all the better, it is necessary to situate his approach in the immediate theological context in which he operated: for his work proceeds here, as on so many other occasions, through an appropriation and a strong re-reading of previously existing traditions. To start with, Milton clearly moves away from any attribution of an intercessory role or of a heavenly superiority to Mary; in this specific aspect, he follows the mainstream Protestant tradition. John Calvin's attention to the character in the Institutes of the Christian Religion, staying safely away from any kind of Mariolatry, had been restricted almost exclusively to attributing to her a place in the lines of descent coming down from David, which in itself would be sufficient to ensure an adequate dynastic position for Christ:

Christ is not said to be made by a woman, but of a woman (Gal 4:4) [...] Wishing to prove that Christ derives his descent from David, he (the evangelist) deems it enough to state, that he was begotten of Mary. Hence it follows, that he assumed it as an acknowledged fact that Mary was of the same lineage of Joseph. (Calvin 2008:307)

In an approach which is essentially coherent with the one taken earlier by Martin Luther, Mary appears here as a channel or a human means through which Christ could become inscribed within the history of "David's seed," thus fulfilling and completing historically the ancient mission of Israel. Calvin certainly recognizes the miraculous nature of the incarnation, but the role that he attributes to Mary in it is little more than instrumental: a position especially favoured by grace and dignified by its physical proximity to the Godhead, but not one that can command a specific and detailed attention, in and by itself, in theological discussion. The approach taken by Milton in Paradise Regain'd will go, as we shall see, much further than this in several aspects, even while accepting the limitation and re-materialisation of Mary's role in contrast to her position in Catholic dogma. If we move closer to Milton's immediate political context, it is possible to appreciate that his approach to the subject owes something to the process of the English Reformation; this becomes clear once we listen to some of the leading theological voices in his time, voices from which his own thought might diverge 
in several essential aspects, but which nevertheless had shared the climate of the English Revolution with him. The theologian John Owen, chaplain to Oliver Cromwell (and an explicit supporter of the execution of Charles I in 1649) had insisted in his treatise of systematic theology, Animadversions Against a Treatise Called Fiat Lux (1671, year of publication of Paradise Regain'd) on the difference between the Catholic veneration of Mary and the Protestant understanding of her dignified yet limited place in the scheme of universal salvation, in the following terms:

The blessed virgin is mentioned in our creed as the person of whom our Savour was born, and we have therefore faith for her; that is, we believe that Christ was born of her. But do we therefore believe in her? Certainly no more than we believe in Pontius Pilate, concerning whom we believe that Christ was crucified under him. [...] We are past charitable hopes that she is ever blessed in heaven, having full assurance of it. (Owen 1671:324)

The abrupt shift in this passage from Mary to Pilate as possible objects of faith is certainly startling, and is an instance of John Owen's polemical intention: his aim is to situate the figure of Mary adequately, not in terms of her virtue or her exemplary role, but simply in order to position her clearly in the discourse of reformed worship. The object of belief must be Christ himself, and any displacement of that belief or trust in any alternative figure, be it Mary or any other, is an unequivocal sign of idolatry. For Owen, Mary has to be seen as one of the elect, and the believer must have "full assurance" that she is "ever blessed in heaven," but that is all: no further characteristics of divinity must be attributed to her, no role of mediation in the human drama of justification before God. Owen's perspective is characteristic of the strong reframing of Mary's role within Protestant doctrine, which excludes her explicitly from worship or faith, but which retains her as a valid example of the qualities of the elect. It is therefore as a human example that Mary can be vindicated: not as an object of belief, but rather as a valid example of the attitude of the believer. This is precisely the direction that was followed by other English theologians in the immediate context of Milton; and here a relevant example is furnished by Matthew Poole, who dedicated a special attention to the figure of Mary in his extensive commentaries on the Gospel of Luke. Poole, who started his career within the context of the Church 
of England, was banished from his post in it because of his dissenting positions, and maintained these even after the Restoration in works such as the Dialogues between a Popish Priest and an English Protestant (1667). It is, however, in his Commentary to the Holy Bible, first published in English 1683, though originally offered to the public in Latin in 1669, that he dedicates a careful attention to Mary as she appears in the Gospel of Luke:

Once I have spoken, but I will not answer. In like manner the virgin speaketh: I will dispute no more, I am the lord's servant, let him do with me what he pleaseth. Her phrase, behold the handmaid of the lord, doth not speak her as the lady and Queen of Heaven, as the papists style her, but it speaketh her humility and readiness to give herself up to God's pleasure, her assent and consent unto God. She added a prayer that God would do according to what the angel had said unto her. (Poole 1683:286)

Once more, the interpretation of Mary is carefully contrasted with Catholic (or, as Poole puts it, papist) traditions: she is not to be seen as queen of Heaven, but as the "handmaid of the Lord:" not exalted beyond human boundaries, as in medieval Mariology, but set as an example of human faithfulness and trust in the Word. Thus her person is desacralized and framed within purely human dimensions, but it is precisely because of this that she can be upheld as a model of personal faith, a valid referent for the community of believers of which she herself is a part.

\section{Waiting with patience (book I.66-104)}

We can now proceed towards our encounter with the character as rewritten by Milton, and it will be necessary for us to begin by listening anew to Mary's only direct monologue in Paradise Regain'd, and by trying to identify the features that would have made it stand out in the poem at the time of its publication, in 1671 . Her voice is heard at the beginning of Book II (lines 66-104), and it is worth noticing that she is not even described physically: the narrator only specifies that she is waiting for her son, and worrying over his absence after he has retired into the desert; that absence has raised "troubl'd thoughts" within her, which are "in sighs thus clad:"

O what avails me now that honour high 
To have conceiv'd of God, or that salute,

Hail highly favour'd, among women blest;

While I to sorrows am no less advanc't,

And fears as eminent, above the lot

Of other women, by the birth I bore,

In such a season born when scarce a shed

Could be obtain'd to shelter him or me

From the bleak air; a Stable was our warmth,

A Manger his; [...] (Paradise Regain'd II.66-75)

The monologue's exordium is a rhetorical question, extended over the first three lines and closed by a semi-colon (rather than a question mark) which projects its contents over the rest of the speech. It phrases the contrast between the honour of being chosen by God and the suffering that it entails: to be "highly favour' $d$ " and "blest" has not brought peace of mind to Mary, but only an increase in sorrows, and this already introduces the main subject of the poem, that will be exemplified in the figure of Christ: the paradoxical coexistence of divine election and human suffering. These first lines are also the most rhetorically complex of the whole speech; the rest of the monologue (the narratio, detailing the subject matter in its chronological development) is structured as a series of vignettes that evoke the main episodes in her life. The remembrance of Bethlehem is especially important, insomuch as it places a key emphasis on the physical conditions surrounding the birth of Christ: in lines 72-75, the very form of the verse tends to enhance the bleakness of the situation through a series of subtle stylistic devices: first, through the alliteration in line 72 ("In such a season born when scarce a shed [...]"), with a gentle play on sibilants; next, through a simple structural parallelism in lines 73-75 that insists on the humble, lowly sites of protection for both mother and child ("me"-"stable", "him""manger", both of them being opposed to the destructive action of the "bleak air"). In this way, the material form of the verse points to the material conditions of the protagonists; the original scene in which Christ enters history is also the scene in which he is first exposed to the elements, and first submitted to the limitations and pains of humanity.

Let us concentrate, before moving onwards in the monologue, on the transcendent significance of this particular insistence on the early suffering of both Mary and her child. From her viewpoint, to evoke that birth is to evoke memories of physical hardship, and this 
is brought about through the very form of the verse, so that the reader is thus led gently but firmly into the central incarnational theme of the poem: the thoroughly material nature of Christ, capable of pain like any other human being. Milton's anti-Trinitarian perspective does not preclude his insistence on the significance of the assumption of flesh by the Son: after all, this is the event that brings about the redemption of humanity, and makes possible the reconciliation between men and God. The non-identity of Son and Father (something that we will have to return to later on) does not modify for Milton the importance of the essential notion of incarnation: on the contrary, the justification of humanity as such is only possible because of the actual existence of the Son in human form, subject to the same kinds of struggles and difficulties that all men experience. No doubt Milton must have always been deeply conscious of the significance of this aspect since his early readings of Church Fathers such as Tertullian, who had insisted on it in his treatise Adversus Marcionem:

The sufferings attested his human flesh, they contumely proved his abject condition. [...] He hungered under the devil's temptation, he thirsted with the woman in Samaria; he wept over Lazarus; he trembled at death (for "the flesh," he says, "is weak"); at last, he pours out his blood. [...] From this, therefore, we have a convincing proof that in it (his flesh) there was nothing of Heaven, because it must be capable of contempt and suffering. (Tertullian 2007:322)

In Paradise Regain'd, the experience of Christ also begins in physical hardship, in his exposure to the "bleak air" of Bethlehem, and it will have as its landmarks his troubled self-exile into the desert (explored in detail through the whole of the poem) and the ultimate agonies of the Passion (not represented in the text, but implicitly present as the culmination of his mission). It is highly significant, however, that the most threatening form that human troubles adopt in the childhood of Christ should be not natural but political. For the bleakest forces against which mother and child have to defend themselves are explicitly identified by her as the kings of the earth:

[...] soon enforc't to flye

Thence into Egypt, till the Murd'rous King

Were dead, who sought his life, and, missing fill'd

With Infant blood the streets of Bethlehem;

From Egypt home return'd, in Nazareth 
Hath been our dwelling many years, his life

Private, unactive, calm, contemplative,

Little suspicious to any King. (PR II.75-82)

The physical event of the incarnation has situated mother and child at the centre of human experience, entailing not only their exposure to natural dangers, but their direct encounter with political conflict; their family life has to be constantly protected from the gaze of the dominating powers of their time and their aggressive intent. Of course, it is not a coincidence that these powers are insistently represented as monarchic (lines 76 and 82); the historical battles through which Milton himself had lived seem thus to insinuate themselves into the fabric of the poem. The maternal spaces evoked are, on the one hand, spaces of rich intimacy, of close contact between mother and son; yet on the other hand they are spaces which are deeply permeated and conditioned by the presence of history, loci where the personal has to define itself dialectically in its relation to external space, and very especially in a political sense. The domestic space, the site of the mother, is certainly idealised in the relationship between herself and the son, but only in that respect: it is certainly not seen as isolated from external reality, as a site of reverie or of liberation from conflict or social turmoil.

Mary's monologue then moves from her autobiographical perspective towards a subject that is openly and explicitly moral: the acceptance of suffering. In the first place, it brings in the subject through the image of Simeon's prophecy, adapted from Luke 2:3435:

[...] I look't for some great change; to Honour? no,

But trouble, as old Simeon plain fore-told,

That to the fall and rising he should be

Of many in Israel, and to a sign

Spoken against, that through my very Soul

A sword shall pierce; this is my favour'd lot,

My Exaltation to Afflictions high;

Afflicted I may be, it seems, and blest;

I will not argue that, nor will repine. (PR II.86-94)

This image had been abundantly commented by the early Church Fathers, who had repeatedly taken it as an emblem of Mary's later suffering at the foot of the cross; in some cases, this very pain had been interpreted as a manifestation of doubt on her part, or as a momentary crisis of faith. This was the case, for instance, of Basil of 
Caesarea, one of the post-Nicene fathers who had been abundantly read by Milton, and who had interpreted the scene in the following terms in his Letter 260:

Simeon called a sword the word that has the power to test and discern thoughts that penetrates unto the division of thoughts, of joints and marrow. Indeed every soul, at the moment of the Passion, underwent a kind of doubt. [...] Even you, O Mary, who learned about the Lord from above, will be affected by doubt. This is the sword. (Gambero 1999:148)

It is not possible to establish a direct textual connection between Basil and Milton here, but it is clear that the poet is thinking, as so often, in terms that are quite close to the Patristic mentality. In Basil the image of the sword not only emblematises and emphasises the notions of uncertainty and suffering, but projects these notions to a later moment in time, the culminating moment of the crucifixion; in Milton, it is read by Mary as anticipating not only the very situation in which she speaks her monologue (missing the adult Christ during his stay in the desert), but the whole of her vital experience in the future. Finally, and in the monologue's conclusio, the reference to the episode of the child Jesus' disappearance and Mary's subsequent discovery of him among the doctors of the Law (Luke 2:46-50) leads to a definitive statement of her existential position:

[...] But where delays he now? some great intent

Conceals him: when twelve years he scarce had seen,

I lost him, but so found, as well I saw

He could not lose himself; but went about

His Father's business; what he meant I mus'd,

Since understand; much more his absence now

Thus long to some great purpose he obscures.

But I to wait with patience am inur'd;

My heart hath been a store-house long of things

And sayings laid up, portending strange events. (PR II.95-104)

The episode of the loss of the child Jesus is read here not only as emblematic of the whole moral attitude of Mary, but as an anticipation of the situation in which she finds herself at the moment of speaking (with Christ lost once more, in the desert this time); both situations imply a similar confrontation with uncertainty and anxiety, and both require a similar firmness in trusting God. The final image in the monologue, an effective example of meiosis in which her heart is compared to a "store-house" of "things/and 
sayings," also works in the same direction, emphasising her sense of herself as a witness and receiver of words and events which are then projected towards the future, "portending strange events." Any possibility of immediate action on her part remains here suspended, but this cannot be read as a position of mere defeatism: on the contrary, it implies the assertion of a constant perseverance in faith in the face of hostile or uncertain circumstances, even though this faith entails the acceptance of hardship.

From what we have seen so far it is already possible to establish some key aspects that can help us to define the Miltonic approach to Mary. This version of the character is characterised by a deep awareness of the passing of time and of the conflictive pressures of history on selfhood; her voice is, above all, expressive of an effort to attune the self to the development of the divine plan in its historical fulfilment, taking strength from the past in order to confront the hardships of the present and to project itself towards the future. ${ }^{1}$ Insofar as the character is explicitly desacralized, and is presented as a modest instrument of God rather than as a paradigm of holiness, it fits coherently with the mainstream Protestant approaches to it; insofar, however, as she develops a specific sense of selfhood, of its relation to history and of its place in it, the character appears as a much more innovative construction, and one which is specifically and characteristically Miltonic.

This kind of self-construction, so alien to our present-day culture, can perhaps be understood better if we take into account Michel Foucault's warning in the prolegomena to his own project for a history of the forms of selfhood (and which he completed only partially, in the three volumes of his History of Sexuality). Foucault argued there that our histories of selfhood should not be focused on the various codes of sexual or moral behaviour, on the external rules of behaviour that are projected on the individual; careful attention must rather be paid to the varieties of inner subjectivation, to the different ways in which selfhood has been articulated and created through different "technologies." Foucault's own history of subjectivity/sexuality was left unfinished, but in its analysis of late classical antiquity and of early Christianity, it left a solid notion of

\footnotetext{
${ }^{1}$ In strict correspondence with the perspective voiced by Mary here, the acceptance of suffering will be explicitly formulated by Christ himself later in the poem (PR III.188194).
} 
self as something that is actively constructed or built through a strenuous effort and through the practices that render it aware of itself, conscious of its need to adopt a specific form in order to fulfil its potential. Commenting on the third volume of the History of Sexuality, Pierre Hadot has underlined the process whereby the self reaches into transcendence, understanding this latter term not in a metaphysical sense, but as signifying its integration into a totalising system. Along with the movement through which "one seeks to be master of oneself, to possess oneself," there is "another movement in which one raises oneself to a high psychic level [...] which consists of becoming aware of oneself as a part of Nature, as a portion of Universal Reason" (Hadot 1989:267). This process is achieved successfully by thinkers as different as Seneca or as Saint Augustine: working under entirely different paradigms, under opposing worldviews, both of these philosophers are able to define forms of selfhood that can situate themselves in relation to an allencompassing totality, whether that totality is defined as Nature or as God. The voice of Mary in Paradise Regain'd (and that of the Son, partially in reflection of his mother's) is likewise expressive of a perspective whereby the self has been able to place itself in relation both to itself and to a wider transcendence.

What Mary's monologue articulates at the beginning of Book II is her particular way of understanding her relation to the field of personal obligations and rules; her way of articulating her subjection to what she perceives as her vital purpose. What this implies for her is nothing more than the conscious and purposeful adequation of the personal will to the will of God (the same process that the poem as a whole delineates, in relation to its protagonist), and the specific form that this process assumes is none other than that of patience. Seen in this light, the character of Mary can be seen as one of Milton's major exemplifications of this "greatest virtue," which he had early on classified in his Commonplace-Book, quoting Lactantius' Seven books on Divine Institutes (probably in its 1578 edition), as the main characteristic of the "good man" (see CPW I.364). As the poet well knew, chapter XIX of Lactantius's Divine Institutes glosses this theme abundantly, putting a major emphasis on the small value that the world will often give to the good Christian, who endures suffering quietly; as Milton had put it in his Commonplace-Book, "it happens that a good man has small value put upon him by all; and because it will be thought that he is not able to defend himself, he will be 
regarded as sluggish and indolent" (quoted in CPW I.364, n.1). The original fragment by Lactantius clarifies and illuminates the full significance of this virtue:

Therefore patience is to be regarded as a very great virtue; and that the just man might obtain this, God willed, as has been said before, that he would be despised as sluggish [...]. Now, if when provoked by injury, he has begun to follow up his assailant with violence, he is overcome. But if he shall have repressed that emotion by reasoning, he is then able to rule himself. And this retraining of oneself is rightly called Patience, which single virtue is opposed to all vices and affections. (Lactantius 1886:185)

Mary's own construction as a "just woman," indeed her very existence as a subject, depends entirely upon her profound integration of the principle of patience, upon her turning that principle into the main practice whereby she regulates her own will. This is the same patience that figures so prominently in so many other moments of Milton's work, the same virtue that speaks allegorically to the poet in sonnet XIX ("When I consider how my light is spent [...]"), and which is recommended to Adam by Michael in book XII of Paradise Lost ("Add virtue, patience, temperance, add love [...]" XII.583). In Miton's later poems, and very especially in Paradise Regain'd, control over the will has a privileged place: it is the sign of the self's adequation to the deployment of a much superior mandate that manifests itself in history, and whose ultimate purpose shall only be completed in a distant time. If the character of Mary as presented in Paradise Regain'd may appear to us simply as a paradigm of passivity, or as merely reactive, deprived of a will of her own, this is only because we are operating within a cultural climate that identifies selfhood with outward activity, and identity with personal assertion. What is at stake in the poem is something rather different: a sustained attempt to configure the self by framing it exclusively within the context of God's plan, and by submitting entirely to it.

It is especially important not to mistake this process of selfcreation for simple quietism or mere passivity: this is the essential oversight that has led an authority such as Stanley Fish to define Mary's position as a "non-response" or a mere "gesture of resignation" to her "genuine needs" (Fish 2002:330). What occurs is in fact, and in a deep sense, the opposite: what the patient self develops is a strenuous and coherent sense of purpose, yet one 
which does not express itself in outward or rash displays of action, but rather chooses to live in a serene and continuous expectation. In this particular form of selfhood, individual action and initiative can be deferred until the moment in which they become necessary, but this deferral only makes them more effective and authoritative when they come. $^{2}$ One such occasion motivates Mary's other key appearance in the poem: a defining moment in which, fulfilling the purpose for which she has learned to wait, she appears as a figure fully endowed with an active power over language and narrative. It is to that moment that we must now turn.

\section{From the mother's word to the word of God (book I.348- 402)}

The fact that Mary has been generally overlooked in critical discussions of Paradise Regain'd might be seen as a proof of her success in the adaptation of her sense of self to the requirements of patience, as I have described them in the previous section. But the poem also shows a complementary side of Mary, specifically the side that is made possible and strengthened through her patient waiting: in her other lengthy appearance in the poem, she not only appears as endowed with the full authority of knowledge, but as responsible for actively guiding and directing her son towards the future fulfilment of his mission. This occurs in a moment that is retrospectively evoked in Book I, in what is Christ's first monologue (PR I.348-402), which he speaks as he is entering the desert, immediately after his baptism.

This particular fragment must doubtless have been especially difficult for Milton, as it involves a stylistic tour de force: here the poet

\footnotetext{
${ }^{2}$ Even though the political discourse of the poem is not the concern of this article, one does not need to to look for a "special identification with the Son" on the part of Milton himself (as some critics have done: see, for instance, Fallon 2007:239-250) to situate the poem firmly within the post-Restoration context. The careful rewriting of the concept of patience that I present here clearly identifies Paradise Regain'd as a text that works towards keeping alive, in the absence of military action, part of the desire for change that had brought about the English Revolution; the idea of accepting a difficult position in the present, of containing any revolutionary impulse, certainly appears again and again in the writings of several English republicans and revolutionaries (authors such as George Wither, John Hutchinson, John Goodwin) between 1660 and 1671, the year in which Paradise Regain'd was published.
} 
must give an appropriate voice to Christ as a literary figure for the first time in the poem, while simultaneously remaining faithful to the truth of the character as expressed in the Gospels. That difficulty is partially solved by allowing the voice of the hero to incorporate, even if very briefly, the accents and the values of the ancient epic: this occurs when Christ remembers the dreams of secular glory that he had harboured in his early childhood:

[...] Victorious deeds

Flam'd in my heart, heroic acts; one while

To rescue Israel from the Roman yoke,

Then to subdue and quell o're all the earth

Brute violence and proud Tyrannick pow'r,

Till truth were freed, and equity restor'd. (PR I.215-220)

These are the aspirations of a potential conqueror and warrior, the kind of fantasies that would have been appropriate for a character in the ancient, aristocratic epic. But they are presented here also as childish desires, and to a certain extent, as arbitrary: they may as easily take the form of leadership over a national liberation ("to rescue Israel from the Roman yoke") as that of a more general, republican or anti-absolutist project ("to subdue and quell o're all the earth $\mid$ Brute violence and proud Tyranni'ck pow' ${ }^{\prime \prime}$ "). It is true that both these projects could be related, to a certain extent, with the political aspirations that Milton himself had in his youth and his adult life, all through the process of the English Revolution: they are not devoid of nobility in themselves, but they are indicative of an early lack of direction, of a vital and psychological restlessness. And it is here that the mother intervenes: the initial ideals of the childish Christ are quickly attenuated and substituted by deeper and more focused ones as, thanks to her, he acquires true knowledge of his own identity and mission:

These growing thoughts my Mother soon perceiving

By words at times cast forth inly rejoyc'd,

And said to me apart: "High are thy thoughts,

O Son, but nourish them and let them soar

To what highth sacred vertue and true worth

Can raise them, though above example high:

By matchless deeds express thy matchless Sire." (PR I.227-233)

Here the domestic space is represented as the site of a privileged relationship between mother and son; it appears as the place where the disciplining of the self is learned and achieved. And the mother's 
presence is truly indispensable to this shift: it is specifically her voice, spoken in the privacy of home, that leads the character to his true destiny through true knowledge of himself, sustained and reinforced by the study of Scripture. This is certainly one of the passages of the poem which must have resonated very differently in 1671 than it does today: except for the fact that the hero of this poem is Christ himself, this kind of self-awakening to one's sense of purpose in life could easily be seen, in the seventeenth century, as an idealised representation of a Puritan coming of age. The boy acquires a new consciousness of his responsibilities not in the public arena, but in the environment of the family, and his sense of duty is strongly reinforced by his reading and study of Scripture (as becomes clear shortly afterwards, in lines 249-251: "I again revolv'd|The Law and Prophets, searching what was writ| Concerning the Messiah [...]") also undertaken at home and through the guidance of the familial (here maternal) authority.

The quintessential difference between the model of motherhood presented by Milton in this passage and those that have been theorised in our own time by psychoanalysis is, in itself, quite significant. The process of growth and development of the self through the family complex that is delineated in this poem could easily be seen as the reverse of the Lacanian description of the formation of selfhood: in Paradise Regain'd it is the mother that brings the boy to a full and rich knowledge of his Father; the Father, in his turn, is not a castrating or destabilising presence, but the enabling force that will oversee the Son's progress towards maturity, and whose influence will guarantee his sense of vital purpose. But above all (and at the farthest possible remove from the Lacanian model) what we have here is the description of a privileged relationship between self and representation, as the words of the mother become the guide that helps the son to situate himself adequately and satisfactorily in the world of language and signification: "[...] By matchless Deeds express thy matchless Sire" (PR I.233). In other words: the mother is here teaching her son to adopt his role as the Son. And in this scene he is not offered an entrance in the world of the Symbolic, where signifiers are perpetually severed from their respective signifiers, and where signs are always fatally divided from themselves. What is suggested here is precisely the opposite: a perfect and stable correspondence between external and internal appearances, so that the "matchless deeds" of the Son will become 
the sign of his "matchless Sire;" indeed it is all a matter of adapting the self so that it becomes indicative of the divine will, fully attuned to it and expressive of it: the young Christ will eventually become a living sign, entirely readable in the terms established by the Father. From a psychoanalytic perspective, a situational paradigm such as this one, in which the paternal presence controls not only language but time and destiny themselves, would offer an ideal occasion for the destruction and destabilisation of the emerging self; and yet the Miltonian perspective sees this all-encompassing perspective as giving a full sense of purpose and direction to the Son, making it possible for him to build his sense of identity. This is the way in which the mother finally leads him to adopt this new awareness:
"[...] they (the Magi) knew thee king of Israel born;
Just Simeon and Prophetic Anna, warn'd
By Vision, found thee in the Temple, and spake
Before the Altar and the vested Priest,
Like things of thee to all that present stood."
This having heard, strait I again revolv'd
The Law and Prophets, searching what was writ
Concerning the Messiah, to our Scribes
Known partly, and soon found of whom they spake
I am; this chiefly, that my way must lie
Through many a hard assay even to the death,
E're I the promis'd Kingdom can attain. (PR I.254-265)

This process is described as a quick, immediate response on his part: a new impulse is awakened within him, focusing and strengthening the uncertain desires that he had harboured until that moment; he moves from the word of the mother to the Word of God. It is in this way that he can know "what was writ" about himself, what was "known partly " by the prophets, but will be fully realised in him: the mother's guidance has led him to establish a new sense of himself by relating his subjective perspective to the divine will as revealed in Scripture. The mother here leads the young Christ towards the Father, and by doing so helps him to acquire a full consciousness of his mission and purpose: the form that the family romance takes in this fragment amounts to a reversal of the Lacanian paradigm. What has happened is best understood from another perspective: we can certainly speak here once more (as we did in the case of Mary's monologue) of a full "construction of selfhood" in Foucauldian terms: a process whereby the subject learns how to become one, and starts a process of interiorization that will enable it 
to construct its consciousness. As Pierre Hadot has specified, commenting on the Foucauldian concept of the "care of the self," the ultimate result of this process is not an absolute sense of independence, but much rather a re-situation of selfhood in relation to a totality, a whole, of which it learns to become a part. This is how Hadot describes this operation in the case of Seneca, one of the protagonists of Foucault's third volume of the History of Sexuality:

The best part of oneself, then, is ultimately a transcendent self. Seneca does not find his joy in "Seneca," but by transcending Seneca; by discovering that he has in him a reason that is part of universal Reason, that is within all the human beings and within the cosmos itself. (Hadot 1989:262)

Despite all the cultural differences between the context of the Senecan access to self-consciousness and the evolution of the young Christ that is described in Paradise Regain'd, the essential aspect remains the same in both cases: self-construction is perceived as the movement towards a sense of a wholeness that transcends the subject, a wider space of signification and meaning in which that subject will find its place and function. The attitude that is encouraged here has nothing to do with simple passivity: we are once again in the domain of patientia, in a process of attunement to the will of God, in full confidence in a future in which action shall indeed become possible: a moment in which political and vital plenitude will be made manifest. It is in this way that the Son is able to become a "transcendent self" in Foucauldian terms: he is able to fit into a universal system, integrating himself, through a process of maturation, into a wider totality determined entirely by the Father. The language of militarism and earthly glory that he had initially used has been discarded, and the kind of desire for self-assertion that it involved has been substituted by something else: just as his desire for renown has been attenuated, so his desire to serve God has become the centre of his personality. This becomes evident in the resolution or conclusio of his monologue, which shows him accepting his present ignorance as to what awaits him in the desert:

[...]And now by some strong motion I am led Into this Wilderness, to what intent I learn not yet, perhaps I need not know; For what concerns my knowledge God reveals. (PR I.290-293) 
Knowledge, for Christ as for his mother, is entirely secondary in selfconstruction: the confidence in the providential plan that both articulate must necessarily involve an attenuation of intellectual anxieties, as much as of the bodily ones. Such a submission of the will does not correspond to the servo arbitrio that Martin Luther had theorised, already established and predestined from the beginning of time for each person: this is a process chosen by the individual whereby he or she, consciously and of his/her own volition, learns to frame him/herself entirely in coherence with the demands of the divine plan. ${ }^{3}$ Thus, the Son learns to live in the "not yet" (I.292) just as the mother has learnt to "wait with Patience" (II.102), and he learns to experience this model of subjectivity as enabling and fulfilling, just as his mother has done before him. In this process of subject-building, the mother not only precedes him, but teaches him: her word is his first and main guide in his gradual discovery of the Word.

It is especially important that we notice the structural and thematic similarities, and especially the proximity in terms of values, between the two monologues spoken by Mary and by Christ that we have discussed, and through which the character of Mary has been defined. Both of them begin by stating a doubt, a sense of unease and insecurity; both proceed towards a narratio (lengthier in the case of Christ, briefer in the case of Mary) that leads them to evoke central episodes in their shared life and in their family home; taking strength in these remembrances, both of them come to accept the indeterminacy of their present situation; finally, in the conclusio of their speeches, both banish any desire for knowledge that should go beyond what God chooses to reveal to them. Both of them also refer to each other thematically, by including references to a shared environment where the virtue of patience has been developed by them: by the mother, through accepting the unpredictability of the Son's actions, and by the Son, through taming all kinds of worldly and military ambition. Rhetorically, both monologues are organized so as to dramatize a learning process, in which the speakers come to understand the need to attenuate personal desire and to "wait with

\footnotetext{
${ }^{3}$ We must not lose sight of the fact that, in the case of Christ, this plan involves his own triumphal return in a better and more favourable future, anticipated in terms which are far from being politically innocent: his final arrival will be "as a stone that shall to pieces dash|All Monarchies besides throughout the world|And of my kingdom there shall be no end" (PR IV.149-151).
} 
patience." Finally, and also in both cases, this waiting, insomuch as it implies a transcendent confidence in the Father and an awareness of the deployment of his will in history, is presented as a the best basis for self-building: it is thus transferred out of the text and established as an exemplary attitude for the reader as well. The process of redemption and justification of humanity in which the reader is asked to put his/her trust has, in fact, been made possible by the incarnational process that has originated in the body and the attitude of Mary: the values that are articulated in her voice define themselves in relation to the process of universal salvation that finds its beginning in her very flesh.

\section{Conclusion}

In this poem, Mary is at the origin of both discourse and action: the origin of the Son's self-discovery (through her language) and the physical beginning of the process of redemption (through her willing involvement in the development of God's plan in history). The feminine is located in this poem precisely at the juncture between narrative and theology, as the link that binds them together and allows them to be informed by each other. There is a clear parallelism between linguistic and incarnational processes here: the body of Mary is in this poem the locus where the historical transformation of humanity is made possible, just as her voice also marks and creates the beginning of the Son's self-recognition, and the definition of his ethical and political projection. The fact that this process of growing self-awareness should occur under the dominating form of patience does not invalidate at all its promise of future action: what patience implies in this poem is precisely, as we have seen, the constant and ongoing persistence of hope under the external appearance of conformity to adverse circumstances.

I would like to conclude by returning, like the poem itself does, to the place of departure: the home of the mother. The very last line in the poem brings her again to the forefront, as her son walks back home from his trials in the desert:

[...] Hee unobserv'd,

Home to his Mother's house private return'd. (PR IV.638-639)

This last line is one of the most conceptually charged in the whole poem: it does not show the protagonist advancing gloriously to his 
sacred mission, but returning home to the mother before even starting it. We, as post-Freudian and post-Lacanian readers, might be tempted to see this return as a purely self-repressive gesture, but this would be an erroneous and decontextualised reading: in this poem, the mother's house is the space where identity and virtue are formed, just as her body is the site where the historical change towards redemption is originated. As a consequence, this last visit to the mother must be seen as yet another enabling gesture: it implies a re-visitation of the major principle that has made both spiritual and moral progress possible, and which has set in motion the narrative of salvation that will now unfold, and which remains outside the reach of the poem. Per exemplum, we readers would also do well, in our subsequent re-readings of Paradise Regain'd, to return to the character of Mary with a full understanding of her complex function as a major, significant presence within it.

\section{References}

Calvin, John 2008. Institutes of the Christian Religion. Trans. Henry Beveridge. Massachusetts: Hendrickson Publishers.

Condee, Ralph W. 1970. “Milton's Dialogue With the Epic: Paradise Regain'd and the Tradition." Yale Review 59: 357-375.

Corns, Thomas N. 2003. "With Unaltered Brow: Milton and the Son of God." Milton Studies 42: 106-109.

Fallon, Stephen 2007. Milton's Peculiar Grace: Self-representation and Authority. Cornell University Press: Ithaca and New York.

Fish, Stanley 2002. How Milton Works. Cambridge, Massachusetts and London: Harvard University Press.

Foucault, Michel 1978-1984. Histoire de la Sexualité, I-III (La Volonté de Savoir) L'Usage des Plaisirs/Le Souci de Soi). Paris: Gallimard.

Gambero, Luigi 1999. Mary and the Fathers of the Church. San Francisco: Ignatius Press.

Hadot, Pierre 1989. Michel Foucault, Philosophe. Paris: Éditions du Seuil.

Lactantius 2007 (1886). "The Divine Institutes." Eds. Alexander Roberts, James Donaldson and Arthur Cleveland Coxe. The Ante-Nicene Fathers vol. VII. New York: Cosimo: 9-327.

Langford, Thomas 1982. "The Nature of Christ in Paradise Regain'd." Milton Quarterly 16: 63-67. 
Lewalski, Barbara 1975. "Theme and Structure in Paradise Regain'd." Studies in Philology 57: 186-220.

Martz, Louis L. 1980. Milton: Poet of Exile. New Haven and London: Yale University Press.

Milton, John 1992. Complete Poems, Of Education, Areopagitica. Ed. Gordon Campbell. London: J. M. Dent and Sons.

Owen, John 1967 (1671). "Animadversions Against a Treatise Called Fiat Lux (1671)." Ed. William H. Goold. Works of John Owen vol. XIV. Edinburgh: Banner of Truth: 318-326.

Pelikan, Jaroslav 1996. Mary through the Centuries: Her Place in the History of Culture. Belknap: Harvard University Press.

Poole, Matthew 1963 (1685). A Commentary on the Holy Bible. Edinburgh: Photographic Reproduction printed by Banner of Truth.

Tertullian 2007 (1885). "The Five Books Against Marcion." Eds. Alexander Roberts, James Donaldson and Arthur Cleveland.The Ante-Nicene Fathers vol. III. New York: Cosimo.

Wayne, Don E. 1984. Penshurst: The Semiotics of Place and the Poetics of History. Madison: University of Wisconsin Press.

How to cite this article:

Curbet Soler, Joan. "Towards a Miltonic Mariology: the word and the body of

Mary in Paradise Regain'd (1671)." SEDERI 22 (2012): 29-50.

Author's contact: Joan.Curbet@uab.cat

Submission: 23/12/2011

Acceptance: 31/01/2012 